\title{
Phytosociology in Agricultural Areas Submitted to Distinct WINTERCROPPING MANAGEMENT ${ }^{1}$
}

\author{
Fitossociologia em Áreas Agrícolas Submetidas a Distintos Manejos de Inverno
}

CONCENÇO, G. ${ }^{2}$, CECCON, G. ${ }^{3}$, SEREIA, R.C. ${ }^{4}$, CORREIA, I.V.T. ${ }^{4}$ and GALON, L. ${ }^{5}$

\begin{abstract}
Studies related to weed dynamics are essential for agricultural sustainability in tropical soils, as their interference can cause significant yield losses, especially in crops with lower competitive ability. This study aimed to assess the composition of weed communities in the third cropping season in areas submitted to distinct wintercroppings for two consecutive years. Evaluations were made in terms of species composition, level of infestation, and severity of occurrence of each weed species in relation to the others within the same area. The wintercropping management systems were: (1) Brachiaria ruziziensis; (2) corn intercropped with B. ruziziensis; (3) corn and (4) cowpea. Plant communities under these wintercrop systems were evaluated in the third year in terms of relative frequency, relative dominance, relative abundance and importance index for each species. Areas were also compared in terms of species composition by the Sørensen's similarity coefficient. Two years of distinct wintercrop managements were not enough to cause a significant shift in terms of weed composition and severity in a given area. There is also evidence that some weed species are more favored by specific crops, although the causes of this selective behavior are not fully explored in this article. The presence of $B$. ruziziensis, either alone or intercropped with corn, resulted in lower similarity coefficients when compared to areas where this species was not present. It is suggested that several mechanisms briefly discussed may be involved in the impact of the presence of $B$. ruziziensis on the weed community.
\end{abstract}

Keywords: weeds, population dynamics, allelopathy, crop rotation, light quality.

RESUMO - Estudos relacionados à dinâmica de plantas daninhas são essenciais para a sustentabilidade da agricultura em solos tropicais, uma vez que a interferência pode causar perdas significativas na produção, especialmente em culturas com baixa capacidade competitiva. Objetivou-se com este estudo avaliar a comunidade infestante em áreas submetidas a distintos manejos de inverno nos dois anos anteriores, em termos de composição da flora infestante, do nivel de infestação e da severidade da ocorrência de cada espécie daninha, em relação às demais, na mesma área. Os manejos de inverno avaliados foram: (1) Brachiaria ruziziensis, (2) milho em consórcio com B. ruziziensis, (3) milho e (4) feijão-caupi. As comunidades de plantas daninhas nesses sistemas de manejo foram avaliadas em termos de frequência relativa, abundância relativa e dominância relativa, eo indice de valor de importância foi calculado para cada espécie em cada área estudada. As áreas também foram comparadas em termos de composição de espécies, pelo coeficiente de similaridade de Sørensen. Dois anos de manejo distinto naárea não são suficientes para ocasionar alterações significativas em termos de composição e severidade de espécies em uma dada área. Há evidência de que algumas espécies daninhas são mais favorecidas pela presença de determinada cultura, embora as causas dessa seleção não sejam completamente exploradas neste artigo. A presença de B. ruziziensis, tanto solteira como consorciada com milho, resultou em menor coeficiente de similaridade quando em comparação com áreas onde essa espécie não estava presente. Sugere-se que vários mecanismos sucintamente discutidos estejam envolvidos no impacto da presença de $\boldsymbol{B}$. ruziziensis sobre a comunidade infestante.

Palavras-chave: plantas daninhas, dinâmica de população, alelopatia, rotação de culturas, qualidade da luz.

Recebido para publicação em 10.7.2011 e aprovado em 19.3.2012

2 Ph.D. in Weed Science, researcher at Brazilian Company of Agricultural Research - EMBRAPA, Western Region Agriculture Research Center - CPAO, Dourados city, Mato Grosso do Sul State, Brazil, <germani@cpao.embrapa.br>; ${ }^{3} \mathrm{Ph} . \mathrm{D}$. in Soil \& Water Conservation, researcher at Embrapa-CPAO, Dourados city, Brazil; ${ }^{4}$ Undergraduate students in Agronomy, trainees at Embrapa-CPAO, Dourados city, Brazil; ${ }^{5}$ Ph.D. in Weed Science, professor at Universidade Federal dos Pampas - UFP, Itaqui city, Rio Grande do Sul State, Brazil. 


\section{INTRODUCTION}

Studies related to weed dynamics are essential for agricultural sustainability in tropical soils, as their interference can cause significant yield losses, especially in crops with lower competitive ability. One of the mechanisms which ensure survival of a given species under constantly disturbed environments, especially for annual plants, is the high number of seeds produced if adult weed plants are not efficiently controlled. Several weed species present high seed production, such as Amaranthus spp. - 120,000 seeds per plant, Galinsoga parviflora -30,000 seeds per plant and Portulaca oleracea 53,000 seeds per plant (Deuber, 1992). In an adverse and constantly disturbed environment these species usually tend to increase their occurrence, covering most of the area and causing more problems for commercial crops (Norsworthy et al., 2001).

Both in dry-tropical and temperate climate areas, crops are grown in the most suitable season and areas usually remain with no economical crops during the rest of the year (Alvarenga et al., 2001). Several studies depict that if these areas are kept with no plant coverage during this period, weed infestations tend to be higher in the next cropping season due to the space available for their establishment and to the seedlings' better accessibility to light (Silva et al., 2007). Under this scenario, these weeds will produce more seeds and the problem of weed infestation will tend to increase in subsequent years.

On the other hand, even when making use of a winter coverage which causes a shift in the number and composition of weeds, some species may be more difficult to control than others (Voll et al., 2005). Understanding not only the rate of occurrence but also the composition of the weed community under each crop rotation system is important in order to achieve efficient weed control. By using the innate suppressive power of crops, it is possible to improve crop productivity significantly and reduce both weed control expenses and harm to the environment (Velykis \& Satkus, 2006).

There are two mechanisms that can be related to a lower infestation and the delayed emergence of seedlings in areas where wintercropping is present. The first being attributed to allelopathic compounds, which could cause direct inhibition of plant growth (Putnan \& DeFrank, 1983; Friebe et al., 1995) as well as a growth stimulus of endophytic fungus capable of attacking seeds at the soil seed bank (Voll et al., 2004). The second mechanism is related to the mulching effect, shading the seedlings of weed species. This is usually more effective in suppressing the development of seedlings of $\mathrm{C}_{4}$ carbon route weed species (Silva et al., 2007).

Phytosociological studies allow for the assessing of species composition of a given canopy and estimation of frequency, relative frequency, abundance, relative abundance, dominance, relative dominance, and the relative importance index for each species in the community, supporting inferences about a given group of plants (Gomes et al., 2010). In addition, it is possible to compare distinct areas which are under the same edaphoclimatic conditions by using the Sørensen`s similarity coefficient.

A phytosociological study starts by sampling the area aiming to identify and quantify the flora present. For this, two methods are most commonly adopted. The Braun-Blanquet (sometimes called Sigma or Relevé) method consists of sampling a single quadrat inside the area, whose size should be pre-determined prior to the study based on a curve of plant diversity. Although Mueller-Dombois \& Ellenberg (1974) describe this method in detail, currently only a few researchers use this method for studies of agricultural systems due to the small size of the experimental plots and the need to adjust the size of the single sampled area. The second method of sampling a plant community is called the Random Quadrat method (Pandeya et al., 1968a; Barbour et al., 1980a). This method requires randomly sampling several points inside the plant community. It is the most widely used and accepted method for studies of weeds. Some researchers cite the Braun-Blanquet method when they are actually using the Random Quadrat method.

After the community is sampled, plants of the weed species should have their severity 
of occurrence estimated based on three parameters: abundance or density (based on the number of plants of the given species in the area); frequency (based on the distribution of the species in the area); and dominance (based on the capacity of the species to overcome the others in terms of use of physical space). Although some authors consider abundance and density as distinct factors, this is not widely accepted because both of them are based on the same factor (number of plants) and thus they are not independent (Pandeya et al., 1968b; Barbour et al., 1980a). The severity of occurrence of each species is obtained by the sum of the three factors: abundance (number of plants), frequency (distribution), and dominance (capacity of overcoming and shading other species).

After areas are characterized, they can be compared by several distinct methods (Barbour et al., 1980b). In this study the Sørensen's coefficient was adopted (Sørensen, 1957). This coerficient is useful for quantifying the level of disconnection between areas after some years of distinct selection factors (Barbour et al., 1980b).

This study aimed to assess the composition of weed communities in the third cropping season in areas submitted to distinct wintercroppings for two consecutive years, in terms of species composition, level of infestation and severity of occurrence of each weed species in relation to the others within the same area.

\section{MATERIAL AND METHODS}

The experiment was installed under field conditions at Embrapa Western Region Agriculture Research Station, Dourados city, Mato Grosso do Sul state, Brazil, located at geographical coordinates $22^{\circ} 16^{\prime} \mathrm{S}$ and $54^{\circ} 49^{\prime} \mathrm{W}$ $408 \mathrm{~m}$ above sea level. The experimental design was completely randomized blocks with four replications. The plot dimension was $10 \mathrm{~m} \times 50 \mathrm{~m}$.

The following treatments were established during the previous two cropping seasons (2008/09 and 2009/10), and their resulting straw constituted the winter coverage of the soil throughout the year:
(T1) Brachiaria ruziziensis; (T2) intercropping of corn and B. ruziziensis; (T3) corn; and (T4) cowpea (Vigna unguiculata). Corn cv. BRS 1010 was drill planted in rows spaced at $90 \mathrm{~cm}$ with 45,000 plants per hectare, for both the corn alone and corn $+B$. ruziziensis treatments. For the intercropped treatment, $B$. ruziziensis was drill planted between corn rows with a final population of 20 plants $\mathrm{m}^{-2}$, whereas the stand alone treatment of this species was drill seeded in rows spaced at $45 \mathrm{~cm}$ with a resultant population of 40 plants $\mathrm{m}^{-2}$. The cowpea treatment was planted with the variety BRS Guariba in rows spaced at $45 \mathrm{~cm}$ resulting in 20 plants $\mathrm{m}^{-2}$. All treatments were planted every year between February and March (late summer - early fall).

At the end of October of the third year, areas were desiccated by using $1.08 \mathrm{~kg} \mathrm{ha}^{-1}$ a.e. of glyphosate, and soybeans were grown for the 2010/11 cropping season over the residual straw left in the areas.

Phytosociological characterization of weed species which emerged from the soil seed bank was carried out in each one of the four previously characterized areas. For that, the method of the Random Quadrats (Barbour et al., 1980a) was used and six areas of $2,500 \mathrm{~cm}^{2}$ in each management system were sampled by the time of soybean planting (beginning of summer). In each sampled area, all the seedlings that emerged were identified, collected and stored by species, being dried in ovens with continuous air circulation for posterior dry mass determination.

For each species present, estimations of relative frequency, relative dominance and relative abundance were evaluated. These variables describe the relationship of each species with the others in the same area. The Importance Value Index (I.V.I.), that describes which species are the most important within the studied area, was also determined according to Mueller-Dombois \& Ellenberg (1974) equations. After these analyses were made, the areas were compared by using Sørensen's similarity coefficient (Sorensen, 1957) to estimate the current degree of weed similarity between areas after 2 years of distinct wintercroppings. 


\section{RESULTS AND DISCUSSION}

The area covered by weeds (Figure 1) depicts treatments involving $B$. ruziziensis, which alone or intercropped with corn showed around $20 \%$ of the area covered by weeds, while corn alone and cowpea alone presented around $42 \%$ of the area covered by weeds. This is due in part to the shading caused by these adult forage plants and also in part due to the almost total absence of soil disturbance in this area in the last 2 years, which probably started forcing part of the soil seed bank to go into a dormant or quiescent state (Severino, 2005).

The number of seedlings and plants of weed species per square meter (Figure 1) showed similarity to the area covered by weeds; however, $B$. ruziziensis grown alone was more efficient in inhibiting the emergence of weeds than the intercropping corn/B. ruziziensis. This is probably due to the fact that when grown alone, $B$. ruziziensis is at a density of 40 plants $\mathrm{m}^{-2}$ while when intercropped with corn its density is 20 plants $\mathrm{m}^{-2}$. This also highlights that corn, as expected, is not capable of shading the soil enough to cause considerable suppression in weed emergence. Cowpea also presented a high number of seedlings of weed species, around $10 \%$ less infested than the plots where corn was grown alone.

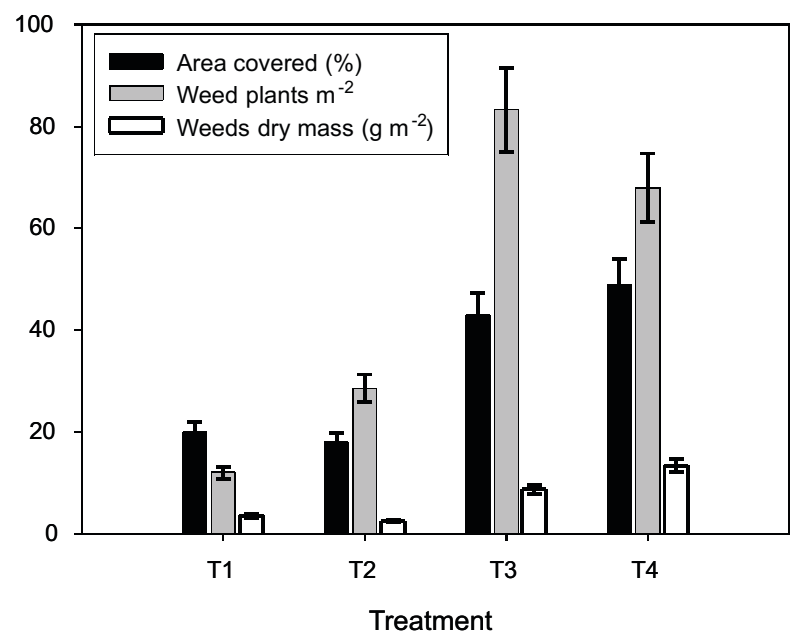

Figure 1 - Weed area coverage (\%), weeds number $\left(\mathrm{m}^{-2}\right)$ and weed dry mass $\left(\mathrm{g} \mathrm{m}^{-2}\right)$ as a function of crop succession, being (T1) Brachiaria ruziziensis grown alone for two years; (T2) Intercropping of corn and B. ruziziensis; (T3) Corn alone; and (T4) Cowpea (Vigna unguiculata) alone. Embrapa Western Region Agriculture, Dourados-MS, 2011
Although the number of plants was higher with the treatment where corn was grown alone, the amount of dry mass accumulated by the weed community was not equally high with this treatment (Figure 1). This means seedlings of weed species were able to emerge with this treatment, but were not able to intercept enough light, either in terms of amount or composition, to enable proper growth of these seedlings. Balbinot Jr. et al. (2007) concluded that corn in its late stages of development may be capable of suppressing weed development, but that this crop is not capable of reducing weed emergence in its early stages due to wide row spacing. Because of that, these authors highlight the requirement that winter crops with Radish (Raphanus sativus), Ryegrass (Lolium multiflorum), Lopsided Oat (Avena strigosa), Rye (Secale cereale) or Vetch (Vicia sativa) allow mulching and adequate initial advantage in the establishment of the subsequent corn crop.

Cowpea treatment presented a more balanced growth of seedlings of weed species: the number of seedlings was smaller than with the corn alone treatment, and the dry mass accumulated by these weeds was higher than the dry mass accumulated with the corn alone treatment. Although the Cowpea allows more homogeneous soil coverage, straw from this crop usually degrades very quickly and in a short period after harvest the soil may be with almost no straw cover. Silva et al. (2010) highlight Cyperus diffusa, Fimbristylis dichotoma and Digitaria horizontalis as the most troublesome weeds in areas of cowpea.

In terms of weed composition, treatment involving wintercropping of $B$. ruziziensis alone presented 13 weed species. Among them, Leonotis nepetifolia was the most abundant, Amaranthus hybridus and L. nepetifolia appeared as the most frequently seen, and Portulaca oleracea was the most dominant (Table 1). When the three factors are analyzed together, $P$. oleracea was the most important weed species in this treatment followed by $L$. nepetifolia. The remainders of the weed species were less important in terms of importance of infestation.

With the treatment involving $B$. ruziziensis intercropped with corn (Table 2), only 6 species 
Table 1 - Phytosociological analysis of weed species and its importance under straw formed after growing Brachiaria ruziziensis alone for two years (T1). Embrapa Western Region Agriculture, Dourados-MS, 2011

\begin{tabular}{|c|c|c|c|c|}
\hline Species & R.Abund. & R.Freq. & R.Domin. & I.V.I. \\
\hline Amaranthus hybridus & 10 & 13.04 & 2.14 & 25.19 \\
\hline Amaranthus retroflexus & 10 & 8.70 & 4.29 & 22.98 \\
\hline Bidens pilosa & 10 & 8.70 & 6.71 & 25.41 \\
\hline Brachiaria decumbens & 10 & 8.70 & 2.24 & 20.93 \\
\hline Chamaesyce hirta & 5 & 4.35 & 2.98 & 12.33 \\
\hline Chamaesyce hyssopifolia & 5 & 4.35 & 1.12 & 10.47 \\
\hline Commelina benghalensis & 5 & 4.35 & 0.84 & 10.19 \\
\hline Conyza bonariensis & 5 & 4.35 & 2.70 & 12.05 \\
\hline Euphorbia heterophylla & 5 & 8.70 & 2.42 & 16.12 \\
\hline Leonotis nepetifolia & 20 & 17.39 & 3.08 & 40.47 \\
\hline Portulaca oleracea & 5 & 8.70 & 70.36 & 84.06 \\
\hline Richardia brasiliensis & 5 & 4.35 & 0.47 & 9.81 \\
\hline Sonchus oleraceus & 5 & 4.35 & 0.65 & 10.00 \\
\hline Total $(\%)$ & 100 & 100.00 & 100.00 & 300.00 \\
\hline
\end{tabular}

were found, with $L$. nepetifolia once again the most important (highest IVI, relative abundance, frequency and dominance), followed by $A$. hybridus in second place. When corn was grown alone (Table 3 ), a high number of weed species was again observed - 11 species, with A. hybridus and Ipomoea grandifolia the most abundant, Commelina benghalensis and $L$. nepetifolia the most frequently seen and I. grandifolia and $L$. nepetifolia the most dominant. The most important weed species were $L$. nepetifolia and A. hybridus (Table 3).

L. nepetifolia was among the most important weed species in these three treatments, while $P$. oleracea was one of the most important when $B$. ruziziensis was grown alone and $A$. hybridus when corn was grown alone or intercropped with $B$. ruziziensis. The species $L$. nepetifolia is considered one of the most important weed species in corn fields (Kissmann \& Groth, 2000); however, these authors also highlight this species as not highly aggressive. On the other hand, some other species like I. grandifolia, despite its abundance, frequency or dominance, may be a more troublesome weed. Morphophysiological characteristics of weed species cause shifts in the competitive ability of weeds against crop species (Karam et al., 2006; Gimenes et al., 2009). Gimenes et al. (2009) also highlight that the high competitive ability of $I$. grandifolia comes from its growth habit, usually rolling itself around corn plants and causing trouble for the mechanical harvest of the crop.

With the treatment of cowpea grown alone, 9 weed species were found, with Bidens pilosa and $L$. nepetifolia the most abundant, $B$. pilosa the most frequently seen, and $A$. hybridus and I. grandifolia the most dominant (Table 4). The most important species according to the I.V.I. were B. pilosa, A. hybridus and L. nepetifolia. As $B$. pilosa was among the most important weed species in this treatment though not

Table 2 - Phytosociological analysis of weed species and its importance under straw formed after intercropping Brachiaria ruziziensis and corn for two years (T2). Embrapa Western Region Agriculture, Dourados-MS, 2011

\begin{tabular}{|l|r|r|r|c|}
\hline \multicolumn{1}{|c|}{ Species } & R.Abund. & R.Freq. & R.Domin. & I.V.I. \\
\hline Amaranthus hybridus & 33.33 & 25 & 24.59 & 82.92 \\
\hline Bidens pilosa & 5.56 & 10 & 21.58 & 37.14 \\
\hline Commelina benghalensis & 11.11 & 20 & 4.64 & 35.76 \\
\hline Euphorbia heterophylla & 5.56 & 5 & 0.41 & 10.97 \\
\hline Leonotis nepetifolia & 38.89 & 35 & 38.39 & 112.28 \\
\hline Melampodium perfoliatum & 5.56 & 5 & 10.38 & 20.94 \\
\hline \multicolumn{1}{|c|}{ Total (\%) } & 100.00 & 100 & 100.00 & 300.00 \\
\hline
\end{tabular}

Table 3 - Phytosociological analysis of weed species and its importance under straw formed after growing corn alone for two years (T3). Embrapa Western Region Agriculture, Dourados-MS, 2011

\begin{tabular}{|l|r|r|r|r|}
\hline \multicolumn{1}{|c|}{ Species } & R.Abund. & R.Freq. & R.Domin. & I.V.I. \\
\hline Amaranthus hybridus & 36.36 & 14.29 & 12.37 & 63.02 \\
\hline Amaranthus retroflexus & 2.27 & 3.57 & 0.57 & 6.41 \\
\hline Amaranthus viridis & 6.82 & 3.57 & 1.56 & 11.94 \\
\hline Bidens pilosa & 4.55 & 10.71 & 9.64 & 24.9 \\
\hline Brachiaria decumbens & 2.27 & 3.57 & 5.39 & 11.23 \\
\hline Brachiaria plantaginea & 2.27 & 3.57 & 11.99 & 17.83 \\
\hline Commelina benghalensis & 9.09 & 17.86 & 9.56 & 36.51 \\
\hline Euphorbia heterophylla & 2.27 & 3.57 & 2.81 & 8.65 \\
\hline Ipomoea grandifolia & 9.09 & 14.29 & 21.02 & 44.39 \\
\hline Leonotis nepetifolia & 22.73 & 21.43 & 24.77 & 68.93 \\
\hline Ludwigia octovalvis & 2.27 & 3.57 & 0.34 & 6.19 \\
\hline \multicolumn{1}{|c|}{ Total (\%) } & 100.00 & 100.00 & 100.00 & 300.00 \\
\hline
\end{tabular}


significant in the other treatments, it is hypothesized that cowpea may both reflect and transmit through its leaves a specific wavelength of sunlight which is efficient in promoting either germination or growth of $B$. pilosa while it may be of no influence for the remainder of the weed species.

The distinct abilities of plant species in reflecting specific wavelengths is extensively discussed by Larcher (2006). Recently in a concept-breaking study, Aspiazú et al. (2010) proved that cassava (Manihot esculenta) plants increased their growth rate, presented a higher photosynthesis rate, and consumed more $\mathrm{CO}_{2}$ when grown under competitive circumstances with small densities of $C$. benghalensis (a slow growth, poorly competitive weed species) than when grown free of competition. In the same study, Brachiaria plantaginea and B. pilosa were highly harmful to cassava plants. These authors highlight that although shoot growth was higher, no differences in root production were observed.

Table 4 - Phytosociological analysis of weed species and its importance under straw formed after growing cowpea (Vigna unguiculata) alone for two years (T4). Embrapa Western Region Agriculture, Dourados-MS, 2011

\begin{tabular}{|l|r|r|c|c|}
\hline \multicolumn{1}{|c|}{ Species } & R.Abund. & R.Freq. & R.Domin. & I.V.I. \\
\hline Amaranthus hybridus & 14.29 & 10.71 & 28.91 & 53.91 \\
\hline Amaranthus viridis & 8.16 & 10.71 & 12.91 & 31.79 \\
\hline Bidens pilosa & 24.49 & 17.86 & 15.18 & 57.52 \\
\hline Chamaesyce hirta & 6.12 & 7.14 & 2.74 & 16.00 \\
\hline Commelina benghalensis & 8.16 & 10.71 & 2.69 & 21.56 \\
\hline Euphorbia heterophylla & 4.08 & 10.71 & 2.34 & 17.13 \\
\hline Ipomoea grandifolia & 2.04 & 3.57 & 24.76 & 30.37 \\
\hline Leonotis nepetifolia & 26.53 & 14.29 & 9.33 & 50.15 \\
\hline Richardia brasiliensis & 6.12 & 14.29 & 1.14 & 21.55 \\
\hline \multicolumn{1}{|c|}{ Total (\%) } & 100.00 & 100.00 & 100.00 & 300.00 \\
\hline
\end{tabular}

This reinforces the competitive principle that a plant that recognizes the imposition of competition applies most of its resources to growth, in detriment of production. This was observed by Aspiazú et al. (2008) in another study where plants of Echinochloa crusgalli changed their leaf/stem relationship by increasing the growth of stems through a mechanism involving shifts in cell water content as a way to increase its height faster, eliminating the competition of smaller plants.

In relation to the similarity coefficients between areas (Table 5), Felfili \& Venturoli (2000) suggest that similarity indexes above 0.50 indicate high similarity between two compared areas, while Looman \& Campbell (1960) suggest that this coefficient should be interpreted in an empirical way. Considering 0.50 as the threshold level, it is possible to highlight that after two years of distinct managements, areas are still very similar in terms of weed composition as all coefficients were higher than 0.50. However, in general numeric terms it is possible to observe that treatments which do not involve the presence of $B$. ruziziensis presented higher similarity coefficients than treatments where this species was present (Table 5).

There are two mechanisms that can be related to the smaller similarity coefficients involving areas where $B$. ruziziensis is present, with the first being attributed to allelopathic issues. Aconitic acid is a substance commonly exudated by grasses such as the Brachiaria species, which is responsible both for direct inhibition of plant growth (Putnan \& DeFrank, 1983; Friebe et al., 1995) and for the growth stimulus of endophytic fungus capable of attacking seeds at the soil (Voll et al., 2004). According to Voll et al. (2010), the aconotic acid affects the soil seed bank and its germination, which results in smaller competitive ability

Table 5 - Sørensen's similarity coefficient (QS) between treatments in terms of weeds infestation after two years of distinct management. Embrapa Western Region Agriculture, Dourados-MS, 2011

\begin{tabular}{|l|c|c|c|c|}
\hline & B. ruziziensis alone & Corn / B. ruziziensis & Corn alone & Cowpea alone \\
\hline B. ruziziensis alone & $\bullet$ & 0.53 & 0.58 & 0.64 \\
\hline Corn / B. ruziziensis & $\bullet$ & $\bullet$ & 0.59 & 0.67 \\
\hline Corn alone & $\bullet$ & $\bullet$ & $\bullet$ & 0.70 \\
\hline
\end{tabular}


of the overall weed community against the crop present in the area.

In conclusion, this work highlights that two years of distinct wintercrop managements are not enough to cause a significant shift in terms of weed composition and severity. It also supplies evidence that some weed species are more favored by specific crops, although the causes of this selection were demonstrated but not fully explored in this article. The presence of $B$. ruziziensis, either alone or intercropped with corn, resulted in lower similarity coefficients when compared to areas where this species was not present. It is suggested that several mechanisms briefly discussed may be involved in the impact of the presence of $B$. ruziziensis over the weed community.

\section{LITERATURE CITED}

ALVARENGA, R. C. et al. Plantas de cobertura de solo para sistema plantio direto. Inf. Agropec., v. 22, n. 1, p. 25-36, 2001.

ASPIAZÚ, I. et al. Photosynthetic activity of cassava plants under weed competition. Planta Daninha, v. 28, p. 963-968, 2010. (Número Especial)

ASPIAZÚ, I. et al. Relação colmos/folhas de biótipos de capim-arroz em condição de competição. R. Trópica, v. 2, n. 1, p. $22-30,2008$

BALBINOT JR., A. A.; MORAES, A.; BACKES, R. L. Efeito de coberturas de inverno e sua época de manejo sobre a infestação de plantas daninhas na cultura de milho. Planta Daninha, v. 25, n. 3 p. 473-480, 2007.

BARBOUR, M. G.; BURK, J. H.; PITTS, W. D. Methods of sampling the plant community. In: BARBOUR, M. G.; BURK, J. H.; PITTS, W. D. (Eds.) Terrestrial plant ecology. Menlo Park: Benjamin/Cummings, 1980a. p. $156-182$.

BARBOUR, M. G.; BURK, J. H.; PITTS, W. D. Methods of describing the plant community. In: BARBOUR, M. G.; BURK, J. H.; PITTS, W. D. (Eds.). Terrestrial plant ecology. Menlo Park: Benjamin/Cummings, $1980 \mathrm{~b}$. p. $183-201$.

DEUBER, R. Ciência das plantas daninhas: fundamentos. Jaboticabal: Funep, 1992. v. 1. 431 p.

FELFILI, J. M.; VENTUROLI, F. Tópicos em análise de vegetação. Com. Técn. Flor., v. 2, n. 2, p. 34, 2000.
FRIEBE, A. et al. Phytotoxins from shoot extracts and root exsudates of Agropyron repens seedlings. Phytochemistry, v. 38, n. 5, p. 1157-1159, 1995.

GIMENES, M. J. et al. Interferência de densidades de Brachiaria brizantha sobre plantas daninhas em sistema de consórcio com milho. R. Trópica, v. 4, n. 1, p. 25-31, 2009.

GOMES, G. L. G. C. et al. Cadastramento fitossociológico de plantas daninhas na bananicultura. Planta Daninha, v. 28, n. 1, p. 61-68, 2010.

KARAM, D. et al. Plantas daninhas na cultura do milho. Sete Lagoas: Embrapa Milho e Sorgo, 2006. 8 p. (Embrapa Milho e Sorgo. Circular técnica, 79)

KISSMANN, K. G.; GROTH, D. Plantas infestantes e nocivas. 2.ed. São Paulo: BASF, 2000. v. 3. 722 p.

LARCHER, W. Ecofisiologia vegetal. São Carlos: RIMA, 2006. $531 \mathrm{p}$.

LOOMAN, J.; CAMPBELL, J. B. Adaptation of Sørensen's $\mathrm{K}$ (1948) for estimating unit affinities in prairie vegetation Ecology, v. 41, n. 3, p. 409-416, 1960.

MUELLER-DOMBOIS, D; ELLENBERG, H. Aims and methods of vegetation ecology. New York: Wiley, 1974. $547 \mathrm{p}$.

NORSWORTHY, J. K. et al. Differences in weed tolerance to glyphosate involve different mechanisms. Weed Technol., v. 15, n. 4 , p. $725-731,2001$.

PANDEYA, S. C.; PURI, G. S.; SINGH, J. S. Synecological methods. In: PANDEYA, S. C.; PURI, G. S.; SINGH, J. S. (Eds.). Research methods in plant ecology. New York: Asia Publishing House, 1968a. p. 79-87.

PANDEYA, S. C.; PURI, G. S.; SINGH, J. S. Structure of an association (phytosociological objectives). In: PANDEYA, S. C.; PURI, G. S.; SINGH, J. S. (Eds.). Research methods in plant ecology. New York: Asia Publishing House, 1968b. p. $88-111$

PUTNAN, A. R.; DeFRANK, J. Use of phytotoxic plant residues for selective weed control. Crop Protec., v. 2, n. 2 , p. 173-181, 1983.

SEVERINO, F. J. Supressão da infestação da plantas daninhas pelo sistema de produção de integração lavoura-pecuária. 2005. $113 \mathrm{f}$. Tese (Doutorado em Fitotecnia) - Escola Superior de Agricultura "Luiz de Queiroz", Piracicaba, 2005

SILVA, M. R. M. et al. Fitossociologia de plantas daninhas na cultura do feijão-caupi em capoeira triturada. In: CONGRESSO BRASILEIRO DA CIÊNCIA DAS PLANTAS DANINHAS, 27., 2010, Ribeirão Preto. Anais... Londrina: SBCPD, 2010. CD-ROM.

Planta Daninha, Viçosa-MG, v. 30, n. 2, p. 297-304, 2012 
SILVA, A. A. et al. Biologia de plantas daninhas. In: SILVA, A A.; SILVA, J. F. (Ed.). Tópicos em manejo de plantas daninhas. Viçosa, MG: Universidade Federal de Viçosa, 2007. p. $17-61$

SØRENSEN, T. A method of establishing groups of equal amplitude in plant sociology based on similarity of species and its application to analyses of the vegetation on Danish commons. Biol. Skrifter, v. 5, n. 4, p. 1-34, 1957.

VELYKIS, A.; SATKUS, A. Influence of crop rotations and reduced tillage on weed population dynamics under Lithuania's heavy soil conditions. Agron. Res., v. 4, p. 441-445, 2006. (Número Especial)
VOLL, E. et al. Chemical interactions of Brachiaria plantaginea with Commelina benghalensis and Acanthospermum hispidum in soybean cropping systems. J. Chem. Ecol., v. 30, n. 7, p. 1467-1475, 2004.

VOLL, E. et al. A dinâmina das plantas daninhas e práticas de manejo. Londrina: Embrapa Soja, 2005. 85 p (Embrapa Soja. Documentos, 260)

VOLL, E.; GAZZIERO, D. L. P.; ADEGAS, F. S. Ácido aconítico em sementes de espécies de plantas daninhas de diferentes locais. Planta Daninha, v. 28, n. 1, p. 13-22, 2010 . 